DOI: $10.11567 /$ met.28.3.3

Machteld Venken

\section{Straddling the Iron Curtain? Immigrants, Immigrant Organizations, War Memories}

Frankfurt am Main: Peter Lang Internationaler Verlag der Wissenschaften, 2011, 206 str.

Knjiga Straddling the Iron Curtain? Immigrants, Immigrant Organizations, War Memories Machteld Venken rezultat je historiografskoga istraživanja provedenog u Belgiji od srpnja 2005. do veljače 2007. o sjećanjima na Drugi svjetski rat, odnosima Istoka i Zapada te migracijskoj povijesti. Predmet istraživanja pripadnici su i pripadnice dvaju migracijskih tokova koji su potkraj Drugoga svjetskog rata u različitim okolnostima imigrirali u Belgiju. U prvome je toku bilo oko 350 bivših poljskih vojnika pridruženih savezničkoj vojsci koji su se nakon oslobođenja Flandrije od nacista u njoj nastanili i oženili Flamankama, a u drugome oko 4000 žena, tzv. Ostarbeiterinnen (radnica s Istoka), porijeklom iz Ukrajine, Rusije i Bjelorusije koje su na prisilnom radu u nacističkoj Njemačkoj upoznale belgijske državljane. Radeći uglavnom na farmama, upoznale su deportirane belgijske radnike, ratne zarobljenike i volontere, s kojima su nakon oslobođenja migrirale u Belgiju, tamo se s njima vjenčale te tako stekle pravo na belgijsko državljanstvo. Iako je određeni broj tih žena bio repatriran u Sovjetski Savez, većina ih je ostala u Belgiji i nije se željela vratiti u zemlju porijekla zbog straha od optužbi za kolaboraciju.

Knjiga je rezultat kvalitativnog istraživanja u kojemu je autorica provela 24 dubinska intervjua $\mathrm{s}$ dvanaest savezničkih vojnika iz Prve poljske oklopne divizije i dvanaest Ostarbeiterinnen. Ističući sličnosti i razlike povezane $\mathrm{s}$ ratnim isku- stvima te dolaskom i naseljavanjem pripadnika dvaju migracijskih tokova, tijekom intervjuiranja pozornost se usmjeruje na prezentaciju priča ispitanika i njihovo oblikovanje. Istražuje se i utjecaj Hladnoga rata te podizanja željezne zavjese između zemalja Atlantskoga i Varšavskog pakta na oblikovanje i artikulaciju ratnih sjećanja odnosno na njihovo kazivanje. Prije analize objašnjavaju se promjene koncepta etničnosti u istraživanjima migracija $\mathrm{i}$ indicira sve veća važnost sjećanja u povijesnim istraživanjima. Polazeći od države i u manjoj mjeri društva kao paradigmatskog okvira istraživanja, »klasični« su povjesničari uvelike pridonijeli amneziji europske bogate migracijske prošlosti, smatra Venken. Za razliku od njih povjesničari (i)migracija počeli su istraživati europsko migracijsko iskustvo te svojim rezultatima pobijati javno mnijenje, koje još uvijek smatra da je »naše» društvo uvijek bilo homogeno (str. 21). Pozivajući se na povjesničara Dinera, koji ističe da su društva tijekom Hladnoga rata ugušila raznolikost narativa o sjećanjima na Drugi svjetski rat, autorica želi oživiti interes povijesti paradigmom sjećanja upozoravajući na krivotvorenost priča o ratnim sjećanjima, njihovu selektivnost i način prezentacije. Nakon pada željezne zavjese rasplamsavaju se i oživljavaju ratna sjećanja jer pojedinci počinju iznositi neispričane priče o ratu i ratnim iskustvima. Sve donedavno znanstvenici su uglavnom slijedili dva traga u artikulaciji sjećanja. Jedan se odnosio na službenu politiku sjećanja, a drugi na svjedočenja sugovornikâ, a nije se posvećivala pozornost uzrocima oblikovanja sjećanja u javnoj i privatnoj sferi, uzrocima prešućivanja ili kazivanja te mogućnostima njihova stalnog preoblikovanja. U ovom istraživanju Venken to nastoji ispraviti. 
Knjiga Straddling the Iron Curtain? Immigrants, Immigrant Organizations, War Memories podijeljena je na tri dijela i šest poglavlja. U uvodnome poglavlju navode se sličnosti i razlike vezane uz iskustvo rata, dolazak i naseljavanje savezničkih vojnika i Ostarbeiterinnen.

U prvom dijelu Constructing group memories (»Konstruiranje grupnih sjećanja«), koje sadržava dva poglavlja, daje se uvid u procese kreiranja grupe i artikulacije sjećanja kod bivših poljskih vojnika pridruženih savezničkoj vojsci i bivših sovjetskih radnica te pridavanje značenja ratnim i migracijskim iskustvima. Analizira se i način na koji formalne i neformalne organizacije i udruženja bivših poljskih vojnika i bivših sovjetskih radnica ulaze $\mathrm{u}$ dijalog s raznim agencijama, odnosno ustanovama u zemlji primitka (Belgiji), ali i porijekla (Poljskoj i Sovjetskom Savezu). Dulje od šezdeset godina, od razdoblja Hladnoga rata pa sve do proširenja Europske unije 2004., te agencije borile su se za pristup kulturnom polju ratnih sjećanja artikulirajući priče i sukobljavajući se oko toga tko treba biti zapamćen. Proces formiranja grupe kod bivših savezničkih vojnika iz Poljske imao je četiri faze. Autoricu najviše zanima posljednjih dvadeset godina. U prvoj je fazi naglasak stavljen na ratna iskustva bivših vojnika i njihovu političku nezainteresiranost. Slijedi dinamičnije razdoblje s izraženijim suparništvom između imigrantskih organizacija. Nova faza nastupa nakon sloma komunizma, a izmijenjeni geopolitički kontekst nanovo oblikuje život imigrantskih organizacija. Poput bivših poljskih vojnika i bivše Ostarbeiterinnen u Belgiji okupile su se u imigrantske organizacije i zajedno artikulirale priče ratnih sjećanja dajući značenje svojim ratnim i migracijskim iskustvima. No njihov organizacijski ustroj i kazivane priče znatno su se razlikovali od priča bivših vojnika. Suprotno formalnim, uglavnom manjim organizacijama bivših boraca, bivše Ostarbeiterinnen okupile su se u jednoj formalnoj organizaciji, Udruzi sovjetskih patriota (SSP), koja je 1953. preimenovana u Savez sovjetskih građana (SSG). Naziv organizacija sugerira njihovu povezanost sa zemljom porijekla, što nije slučaj s imigrantskim organizacijama bivših poljskih vojnika. Proces formiranja grupe kod bivših je sovjetskih radnica stoga bio gotovo isključivo orijentiran na njihova društva porijekla. S obzirom na marginaliziranost SSP-a i poslije SSG-a u službenim sovjetskim i belgijskim pričama ratnih sjećanja tijekom komunističkog razdoblja, u knjizi se propituju mehanizmi koji su na to utjecali. Postkomunistička Rusija razvila je različita kulturna područja na kojima su razne agencije artikulirale priče ratnih sjećanja, pa su tu svoje mjesto našle i priče bivših Ostarbeiterinnen. One su neprestano lobirale za svoje mjesto u službenome ruskom ratnom sjećanju. Ponekad ih se predstavljalo kao junakinje, aktivne ženske borce za slobo$\mathrm{du}$, dok ih se u nekim drugim razdobljima prepoznavalo kao ratne žrtve. Autorica nadalje analizira razlike između muškaraca i žena s obzirom na belgijsku migracijsku i naturalizacijsku politiku. Istražuje razgranavanje tih razlika tijekom njihova dolaska i procesa doseljavanja u Belgiju. Iako nisu dobili belgijsko državljanstvo odmah nakon vjenčanja s belgijskim državljankama, bivši poljski vojnici brže su se i lakše integrirali u belgijsko društvo od bivših sovjetskih radnica, koje se često etiketiralo i omalovažavalo, nazivalo ih se ratnim prostitutkama i komunistkinjama i većinsko ih je društvo percipiralo kao autsajderice. U isto su vrijeme bivši poljski vojnici pridruženi savezničkoj vojsci puno bolje kotirali jer ih je većina Belgijaca doživljavala kao pripadnike hrabrih divizija koje su oslobodile Flandriju. 
Performing group memories (»Izvođenje grupnih sjećanja«) naziv je drugog dijela knjige, sastavljenog također od dva poglavlja. U prvome se autorica zadržava na komemorativnoj svečanosti na groblju u Lommelu koje je tijekom Hladnog rata predstavljalo zanimljivu arenu sučeljavanja priča o ratnim sjećanjima. Na jednoj strani nalazili su se poljski imigranti, koji nisu priznavali legitimnost Poljske Narodne Republike, a na drugoj čelnici belgijske Komunističke partije zajedno s poljskim konzulatom u Belgiji. Predstavnici obaju političkih tabora u svoje su priče o ratu uključivali sjećanja na ubijene divizijske vojnike da bi opovrgnuli priče drugoga tabora. Oni su rekonstruirali svoju viziju prošlosti lommelskoga groblja te tako legitimirali svoj položaj unutar geopolitičkog okvira Drugoga svjetskog rata. Važno je bilo ispitati doživljavanje prošlosti, a ne samo puki sadržaj grupnih sjećanja. Prakse pamćenja pružile su kontekst u kojemu su se sjećanja sudionikâ oblikovala. Autoricu zanima utjecaj artikuliranih priča o ratnim sjećanjima izgovorenih na godišnjim komemoracijama u Lommelu na pojedinačna sjećanja bivših poljskih vojnika. Također se demonstrira opseg do kojega su pojedinci usvajali priče pojedinih organizacija o ratnim sjećanjima, odnosno utjecaj javne prezentacije na sjećanja.

U trećem dijelu knjige Trauma in group memories (»Trauma u grupnim sjećanjima«), koje se sastoji od samo jednog poglavlja, analiziraju se poslijeratni životi ispitanika s obzirom na iskustva nanošenja ozljeda tijekom rata. Autorica polazi od antropologa P. Connertona, koji je 1980. prvi progovorio o konceptu tjelesnog sjećanja tvrdeći da se sjećanje uvijek događa kroz tijelo i pomoću tijela. Nadovezujući se na njegov rad, Venken istražuje izvođenje sjećanja tijela tijekom vremena unutar dva imigrantska društvena en- titeta: imigrantskih organizacija i obitelji, usmjerujući se posebno na njihovu interakciju.

Iako su tjelesna sjećanja obično tema antropoloških i psiholoških istraživanja, Venken smatra da ona mogu biti zanimljiva i povjesničarima. No kako povjesničari mogu istraživati netekstualnu i često nesvjesnu artikulaciju tjelesnih sjećanja u prošlosti? Je li »nijema« sjećanja moguće pronaći u napisanim tekstovima i usmenim izvorima? Mogu li povjesničari uopće artikulirati tjelesna sjećanja interpretirajući primjerice slike ili fotografije kad nema nikoga tko će riječima potvrditi ono što je na njima prikazano? Takve i slične nedoumice povezane s povijesnim razumijevanjem detaljno je istraživao Dominick LaCapra, na kojega se autorica također poziva, upozoravajući na važnost preživjelih sudionika nekog prošlog događaja u artikuliranju tjelesnih sjećanja. S obzirom na to da je ratna trauma ne samo individualno nego i kolektivno iskustvo i može »kreirati« kolektivitete traumatiziranih ljudi, ona je interesantna i sociolozima (Erikson, str. 151). Prema sociologu Jeffreyju Alexanderu, kolektivna identifikacija s traumom zbiva se kada »članovi kolektiviteta osjećaju da su bili predmet zastrašujućeg događaja koji je ostavio neizbrisiv trag na njihovu grupnu svijest zauvijek označujući njihova sjećanja te temeljito i neopozivo mijenjajući njihov identitet« (Alexander, str. 151). Od 1990. sociolozi sve više istražuju traumu, preusmjerujući fokus s patologije na kolektivnu socijetalnu dinamiku pod pretpostavkom da je trauma društveno konstruirana.

Iako na prvi pogled namijenjena povjesničarima, knjiga Straddling the Iron Curtain? Immigrants, Immigrant Organizations, War Memories Machteld Venken pruža važne informacije i znanstvenicima koji se bave migracijama, posebno druš- 
tvenom integracijom imigranata, (i)migrantskim udruženjima te migracijskim i integracijskim politikama. Ali zbog interdisciplinarnosti, posebno izražene $u$ teorijsko-konceptualnom okviru, metodama i nalazima istraživanja, ona će biti zanimljiva i sociolozima, politolozima, antropolozima, psiholozima i drugima. No možda će u njoj ipak najviše uživati znanstvenici koji se bave historijskom sociologijom, $\mathrm{i}$ to iz nekoliko razloga. Jedan je upotreba tzv. pristupa bottom-up (odozdo prema gore), kojim se osvjetljavaju dinamika moći i međuodnos dominantnih agencija te njihov utjecaj na artikulaciju ili prešućivanje ratnih sjećanja. Za historijsku sociologiju zanimljiv je i utjecaj političke podjele društva nakon sloma komunizma na etnifikacijske procese. (I)migranti poljskoga etničkog porijekla u Belgiji nakon pada željezne zavjese bivše su savezničke vojnike iz Poljske nastojali »poetničiti«, dok je kod bivših Ostarbeiterinnen došlo do etničke transnacionalnosti. Krajem osamdesetih godina 20. stoljeća ljudi su počeli ponovno promišljati o Drugome svjetskom ratu prevrednujući ga, nadopunjujući i mijenjajući sadržaj pamćenja u odnosu na onaj u eri Hladnoga rata. Nakon pada željezne zavjese dolazi i do svojevrsne europeizacije ratnih sjećanja jer je ratna iskustva zbog društveno-političkih i ideoloških promjena bilo moguće smjestiti pod isti kišobran. Na taj je način, kada je o ratnim sjećanjima riječ, olakšano uvođenje transnacionalnih europskih meta narativa (str. 270). Ako dakle prihvatimo tvrdnju da su imigrantska ratna sjećanja konstruirana i artikulirana u stalnom pregovaranju s agencijama iz zemalja porijekla i primitka, kao što se pokazalo u nalazima istraživanja Machteld Venken, tada bi istražujući ih to uvijek valjalo imati na umu. Kada su posrijedi historiografska istraživanja, možda je to i najveći doprinos ove knjige.

\section{Snježana Gregurović}

Institut za migracije i narodnosti, Zagreb 